\title{
HLUBOKÁ ANALÝZA SOUČASNÝCH PROBLÉMŮ FINANČNÍHO SEKTORU A EKONOMIKY
}

Kamil Janáček ${ }^{*}$

\section{Mervyn King: The End of Alchemy (Money, Banking and the Future of the Global Economy).}

Londýn: Little, Brown, 2016. ISBN 10:1408706113.

Kniha člověka, který prakticky celý svůj profesionální život spojil s centrálním bankovnictvím (byl dlouhá léta hlavním ekonomem, posléze viceguvernérem a 10 let guvernérem Bank of England), je hlubokou analýzou současných problémů finančního sektoru a ekonomiky - a sžíravou kritikou hospodářských politik vlád a zejména měnových politik centrálních bank.

Z četných postřehů a závěrů M. Kinga bych chtěl upozornit zejména na tyto:

1. Velké dynamické modely, které centrální banky používají pro predikci vývoje ekonomiky a inflace, neř́kají vůbec nic o významu peněz a bank, nebot' neobsahují finanční sektor. Navíc mají tu vlastnost, že - z povahy modelu - ve středním období se inflace vždy vrací k cíli. (Obdivuhodná sebekritika od člověka, za jehož působení byl vypracován dynamický model, který použivá převážná většina centrálních bank cílujících inflaci. Tuto pasáž by měli číst všichni centrální bankéři od Washingtonu přes Frankfurt až po Prahu.) Tento problém se snaží výzkumníci v největších centrálních bankách řešit - at' již pokusy začlenit finanční sektor přímo do modelu, nebo vytvořit satelitní model, zahrnující finanční a bankovní sektor. Bohužel prozatím bez úspěchu.

2) „Alchymie“ centrálních bankéřů s neortodoxními nástroji měnové politiky pokračuje. Znepokojující je, že po největší finanční krizi v moderní historii se nic podstatného nezměnilo ani ve struktuře bankovnictví ani ve spoléhání na to, že centrální banky pumpováním peněz do ekonomiky obnoví hospodářskou prosperitu. Pokračující spoléhání na měnovou politiku a neschopnost reálného přizpůsobení je chybou jak teorie, tak praxe.

3) Velkou hrozbou pro dnešní světovou ekonomiku jsou přetrvávající nerovnováhy mezi výdaji a úsporami jak uvnitř, tak mezi ekonomikami. Jedním z možných řešení těchto nerovnováh je návrat k plovoucím kurzům měn. Experiment s fixními kurzy měn nebyl úspěšný - měnovým kurzům je tř̀eba vrátit jejich stabilizační úlohu při korigování nerovnováh.

* Kamil Janáček (kamil.janacek@vse.cz), Vysoká škola ekonomická v Praze, Národohospodářská fakulta. 
4) Existuje velké nebezpečí a riziko, pokud očekáváme od centrálních bank více, než ve skutečnosti mohou vykonat. Mnoho lidí - zejména politiků - si myslí, že centrální banky a jejich politika jsou odpovědí na všechny naše problémy. Nakonec se může stát, že přehnaná očekávání o možnostech centrálních bank se zvrátí v deziluze o jejich úloze, což může ohrozit jejich nezávislost.

5) Nové formy regulace, její zpř́ísňování sice činí banky o něco odolnějšími, ale nezměnily nic zásadního na struktuře bankovnictví. Jako vždy reagují na minulé problémy, aniž se snaží řešit skutečná slabá místa systému.

6) Politika nízkých úrokových sazeb centrálních bank je omylem a velkým nebezpečím. V 19. století a po většinu 20. století se reálná úroková míra pohybovala mezi 3-5\%. Od devadesátých let 20. století reálná úroková míra klesla nejdříve ze $4 \%$ na $1,5 \%$, aby v poslední době dosáhla téměř $0 \%$. To je podnětem pro investice s nízkou mírou návratnosti (nákupní a administrativní centra), nikoliv pro produktivní investice, které prrinášejí inovace a růst produktivity. To je též jeden z důvodů poklesu temp růstu produktivity, hrubého domácího produktu a obnovení hrozby takzvané sekulární stagnace. Za této situace měnová politika není sice úplně impotentní, nicméně podléhá zákonu klesajících výnosů.

7) Schopnost centrálních bank konat v dobách finančních a hospodářských krizí závisí na jejich legitimitě. Ta se buduje dlouhé roky, zejména zvyšováním odpovědnosti a transparentnosti jejich rozhodování. Centrální bankéři si však musí uvědomit, že neexistuje žádné trvalé pravidlo pro jejich rozhodování, které zůstává platné donekonečna.

Nicméně závěr knihy M. Kinga je uměřeně optimistický, když říká: „Kapitalismus zdaleka není perfektní. Ale je to nejlepší cesta, jak vytvářet bohatství. Vytváŕí podněty pro inovace, které podporují růst produktivity. Pouze lidé, kteří mohou svobodně vynalézat, hledat nové nápady, rozvíjet je a realizovat, jsou schopni přetvořit tyto myšlenky inovace - v růst produktu, produktivity a bohatství."“

\section{Tisková oprava}

V minulém čísle časopisu Politická ekonomie došlo k tiskové chybě v nekrologu prof. Ing. Lubomíra Cyhelského, DrSc., a to k špatnému uvedení biografických údajů. Správné údaje jsou: * 12.10.1929-†22. 1. 2018.

Za tuto chybu se omlouváme, autoři článku s ní nemají nic společného.

Redakce 